\title{
43. PHENOMENA OF PULSATION TECTONICS RELATED TO THE BREAKUP OF THE EASTERN NORTH AMERICAN CONTINENTAL MARGIN ${ }^{1}$
}

\author{
Robert E. Sheridan, Department of Geology, University of Delaware, Newark, Delaware
}

\begin{abstract}
New data from the recent IPOD drilling at Deep Sea Drilling Project Site 534 in the Blake-Bahama Basin give a definitive age for the spreading-center shift involved in the breakup of the North American Atlantic margin. An age of basal Callovian ( $\sim 155$ m.y.) is determined for the Blake Spur magnetic anomaly marking this spreading-center shift that signals the birth of the modern North Atlantic Ocean. This age is some $20 \mathrm{~m}$.y. younger than previously thought. One implication of this result is that this spreading-center shift starting North Atlantic drifting is now of an age that could be assigned to the spreading-center shift needed to end the drifting in the Gulf of Mexico. It is suggested that this might be one and the same event. Another implication of this young age for the Blake Spur event is that very high spreading rates are now required for the Jurassic outer magnetic quiet zone along the North American margin. This association of a relatively high spreading rate with a magnetic quiet zone is similar to that for the mid-Cretaceous and implies a link between the processes controlling plate spreading, which are in the upper mantle, and the processes controlling the magnetic field, which are in the outer core. A theory of pulsation tectonics, involving the cyclic eruption of plumes of hot mantle material from the lowermost mantle, could explain this correlation. Plumes carry heat away from the core/ mantle boundary and later reach the asthenosphere and lithosphere to induce faster spreading. The pulse of fast spreading in the Jurassic apparently caused the breakup of the North Atlantic. Other pulses of fast spreading appear to correlate with major ocean openings on various parts of the globe, implying that this might be a prevalent process. Rifting of passive margins might be controlled by the more fundamental global processes described by the theory of pulsation tectonics.
\end{abstract}

\section{INTRODUCTION}

As part of Leg 76 of the International Phase of Ocean Drilling (IPOD) of the Deep Sea Drilling Project (DSDP), drilling was completed at Site 534 in the BlakeBahama Basin in December, 1980 (Fig. 1). The BlakeBahama Basin is a unique spot in the North Atlantic, for there the geologic history of slow abyssal sedimentation during the Maestrichtian through Eocene, coupled with some minor erosion in the Paleocene and Oligocene, has maintained a thin sedimentary section over a relatively shallow oceanic basement. Consequently oceanic basalt could be drilled at approximately $6610 \mathrm{~m}$, well within the $6800-\mathrm{m}$ engineering drill string limit of the Glomar Challenger (Fig. 2).

High-quality multichannel seismic reflection profiles are available at the Site and in the area of the Blake-Bahama Basin and Blake Escarpment. A summary of the available seismic data is discussed by Sheridan et al. (this volume). Those lines directly at Site 534 were collected on Cruise 2102 of the Robert Conrad of Lamont-Doherty Geological Observatory (Bryan et al., 1980). These lines have been interpreted as part of a study on the origin of Horizon D, the prominent reflector that bounds the oldest seismic unit in the Basin (Fig. 3). The D to basement unit is slightly more than $200 \mathrm{~m}$ thick in the center of a northwest-southeast trending fracture-zone trough between Sites 391 and 534 (Sheridan et al. this volume). The Challenger could only reach basement on the flanks of this trough, and Site $\mathbf{5 3 4}$ was selected where

\footnotetext{
${ }^{1}$ Sheridan, R. E., Gradstein, F. M., et al., Init. Repts. DSDP, 76: Washington (U.S. Govt. Printing Office).
}

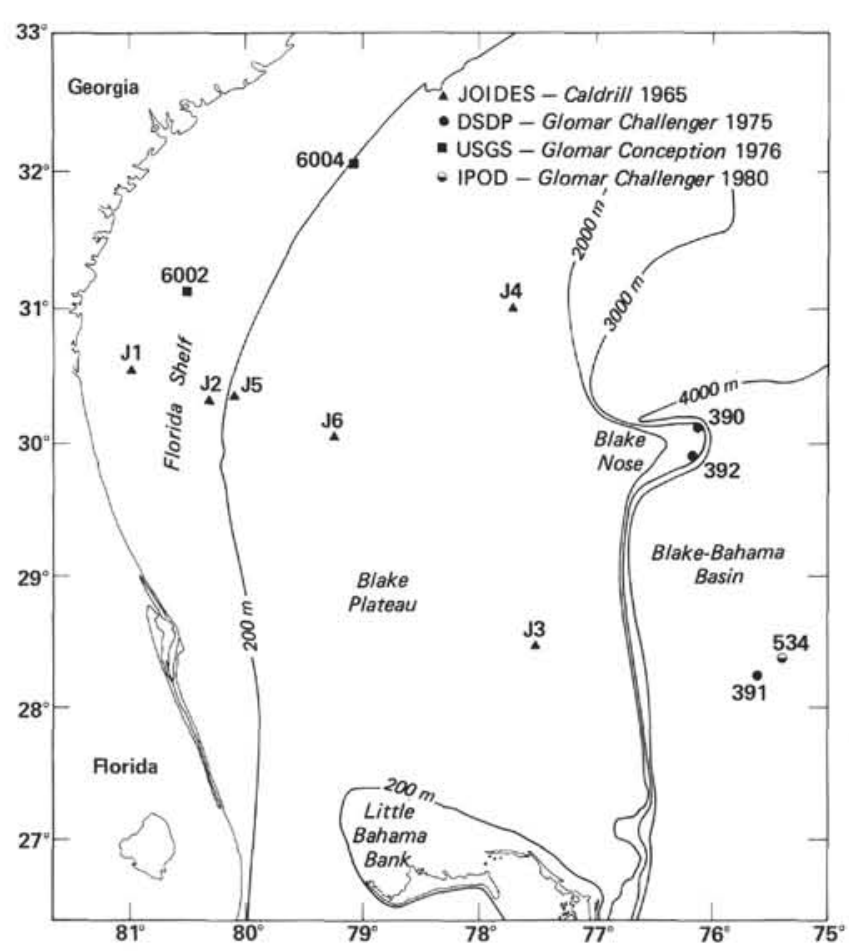

Figure 1. Location map showing the drill sites in the Blake Plateau, Blake-Bahama Basin area drilled strictly for scientific purposes.

contourite deposits had onlapped the basement. It can be interpreted that the oldest hemipelagic clays were carried by the weak bottom currents flowing through the fracture zone and were deposited up on the shallower basement (Sheridan et al., this volume). 


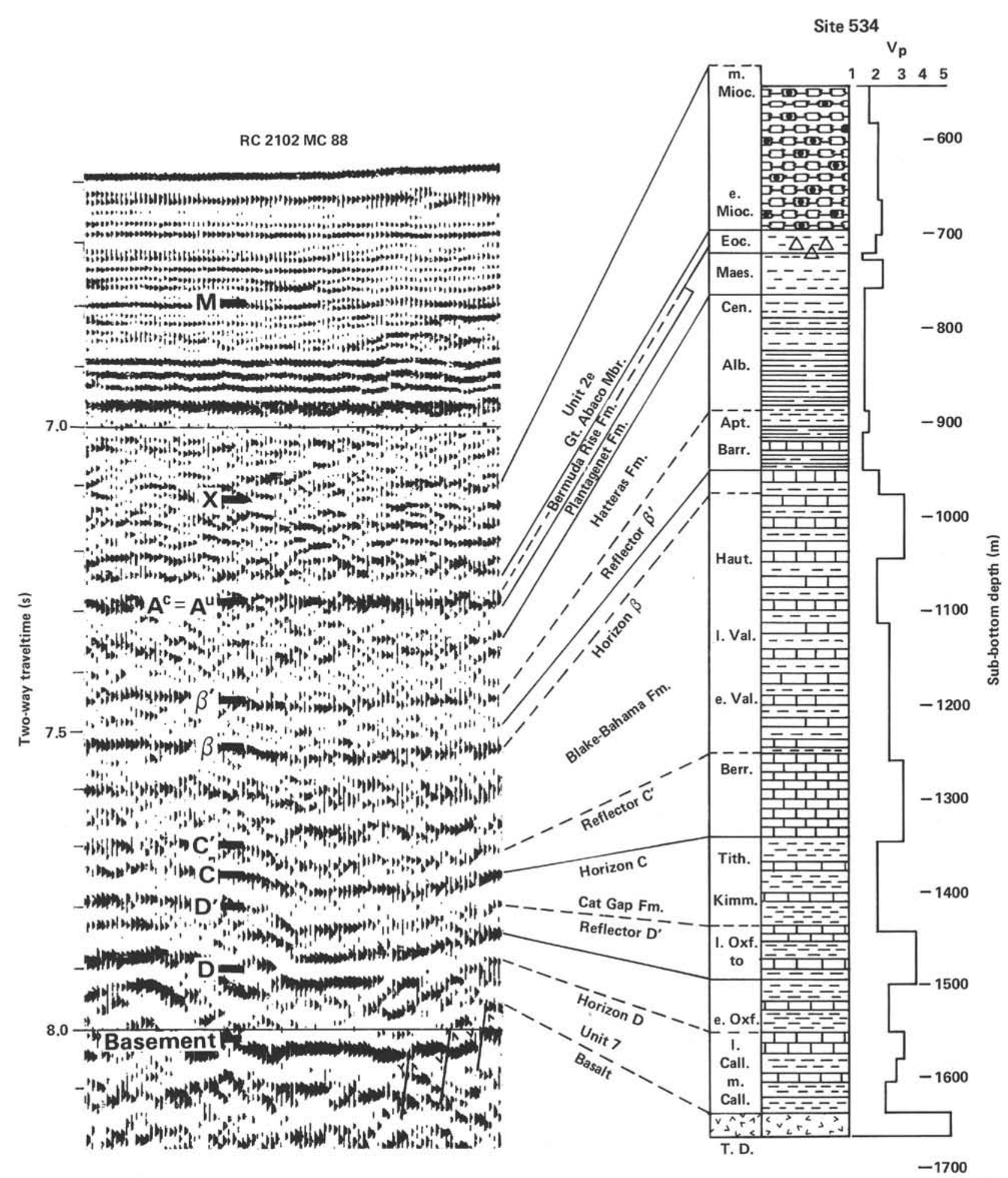

Figure 2. Drilling results at IPOD Site 534 showing correlations to the nearby Robert Conrad seismic reflection profile. (The formation boundaries are indicated by solid lines, the reflector correlations by dashed lines. The average laboratory velocity $\left(\mathrm{V}_{\mathrm{p}}\right)$ is plotted with the lithologic column.)

Until the drilling at Site 534, the sediments beneath Horizon D-the oldest sediments in the western North Atlantic in reach of Challenger's drill-had never been sampled. Previous drilling at Site 391 and other sites in the North American Basin had sampled all the younger stratigraphic formations (Fig. 2). The formation no- menclature used in this paper is after Jansa et al. (1979). Drilling and coring at Site 534 penetrated and recovered all the younger formations of the North American Basin, and it was quite evident when a new formation was penetrated beneath the Cat Gap Formation, the oldest unit previously drilled. The red shaly limestone and in- 


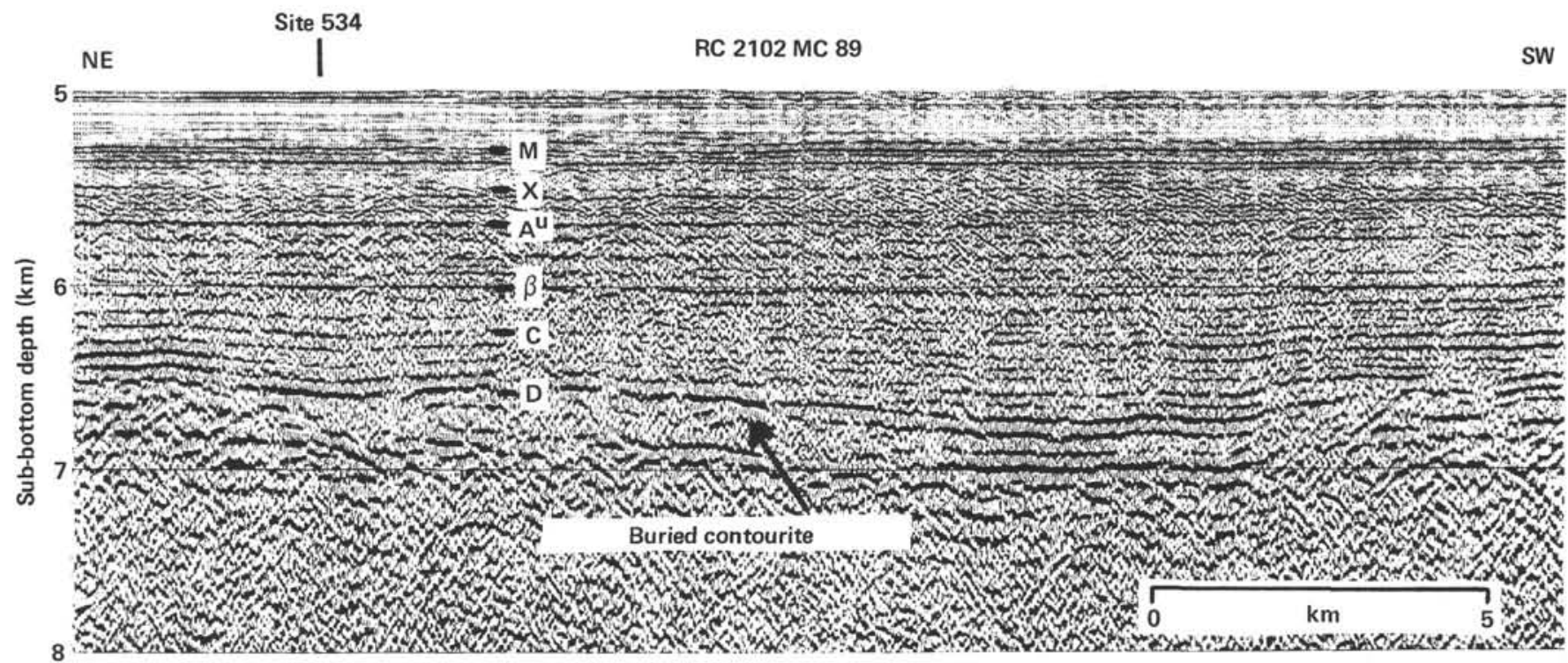

Figure 3. Multichannel seismic reflection profile made from the Robert Conrad near IPOD Site 534 in the Blake-Bahama Basin. (Key reflection Horizons $\mathrm{M}, \mathrm{X}, \mathrm{A}^{\mathrm{u}}, \beta, \mathrm{C}$, and $\mathrm{D}$ are indicated, and hummocky reflectors of asymmetric mounds of contourite deposits are located. Horizon $\mathrm{D}$ is a basin-leveling deposit covering the topographic trough in basement southwest of Site 534.)

terbedded gray turbidite limestone of the Cat Gap Formation overlie a green, maroon, dark red, and black claystone that is highly siliceous and radiolarian rich. This claystone in turn overlies basaltic basement at a sub-bottom depth of $1635 \mathrm{~m}$. Sedimentary structures and textures in the claystone unit include sharp top and bottom contacts, thin bedding, lenticular bedding of starved ripples, low-angle cross-bedding, clay balls and erosive phosphatic pavements, and concentrations of silt-size microfauna in what might be winnowed microfossil placers. These sedimentary features are evidence for bottom-current transport, which agrees with the seismic evidence for contourite deposition of the oldest unit (Sheridan et al., this volume). Some thin (10-30 cm) layers of claystone show evidence of penecontemporaneous slumping of the soft clay sediment, probably off the local oversteepened slopes of contourite mud ridges.

Horizon D is correlated with a several-meter-thick sequence of horizontally bedded gray carbonate turbidite that tops the dipping contourite muds. This is just as it appears in the seismic reflection profiles (Fig. 3), which show Horizon D as a basin-leveling event that at some point in time, in this case the early Oxfordian, covered the more asymmetric hummocky hemipelagic deposits that drape the basement.

Good biostratigraphic dating by nannofossils gives an age of no older than middle Callovian (153 m.y., using the van Hinte [1976] time scale) for the oldest sediments recovered on oceanic basement at Site 534 (Site 534 report, this volume). Thirty meters of basaltic basement were cored, and many thin layers of pillow-lava flows were recovered. Those were identified by vesicular zones and glassy margins of individual pillows, and the associated intercalated sediments. The intercalated sediments, although highly altered, contained pelagic pelecypod filaments that correlate with Callovian deposits in the Tethyan area.

\section{SPREADING RATE IMPLICATIONS}

Site 534 is well located in a corridor with a good detailed magnetic anomaly map (Bryan et al., 1980) (Fig. 4). The detailed magnetic map shows the precise positions of magnetic Anomaly M-25 and the Blake Spur anomaly, which are the largest-amplitude, linear anomalies bounding the Jurassic outer magnetic quiet zone on the southeast and northwest, respectively. Within the magnetic quiet zone there are weakly defined, small-amplitude northeast-striking negative anomalies that have been assigned the nomenclature M-26 through M-28 (Bryan et al., 1980). This nomenclature was after Barrett and Keen (1975) who found what they believed were actual reversely magnetized blocks in about the same positions in the quiet zone off Nova Scotia. Now, however, it is felt that Barrett and Keen (1975) confused their M-26 through -28 anomalies with the end of the Keathley sequence, M-24 through -25 . M-26 is the one anomaly that is more certain to be a true reversal, in that it is found as a series of reversals in the Pacific Jurassic quiet zone (Cande et al., 1978). In the Pacific the nomenclature of M-26 through M-29 is equivalent to M-26 in the Blake-Bahama Basin. Site 534 is located near the southeast boundary of Anomaly M-28, and on the north rim of a more circular negative anomaly associated with a "zero offset" fracture zone between Sites 534 and 391.

Spreading rates across the Jurassic outer quiet zone of the western North Atlantic had been estimated previously by several techniques (Fig. 5). Vogt and Einwich (1979) presumed a constant spreading rate across the quiet zone based on drill-site control, such as Sites 100 and 105, and 387 in the western North Atlantic on Anomalies M-25 and M-16, respectively. The equivalent constant rate at Site 534 would be $1.5 \mathrm{~cm} / \mathrm{yr}$., assuming the van Hinte (1976) time scale. Fortuitously, this spread- 


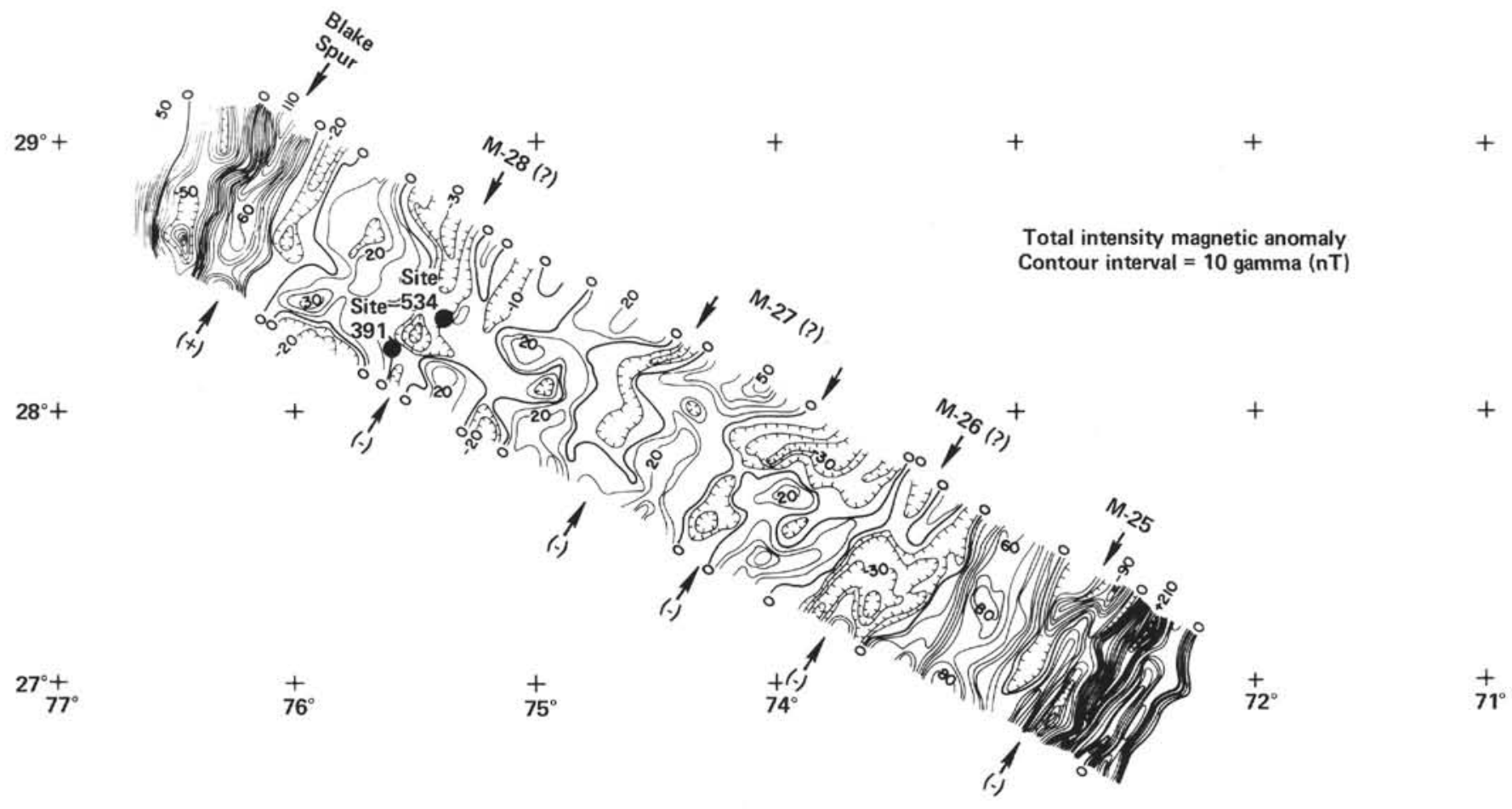

Figure 4. Detailed magnetic anomaly map made from the Eastward across the Blake-Bahama Basin in the area of Sites 391 and 534 . Located are the linear anomalies Blake Spur, M-25, and the tentative correlation of M-26 through -28 . The M-26 through -28 terminology is after Barrett and Keen [1975].

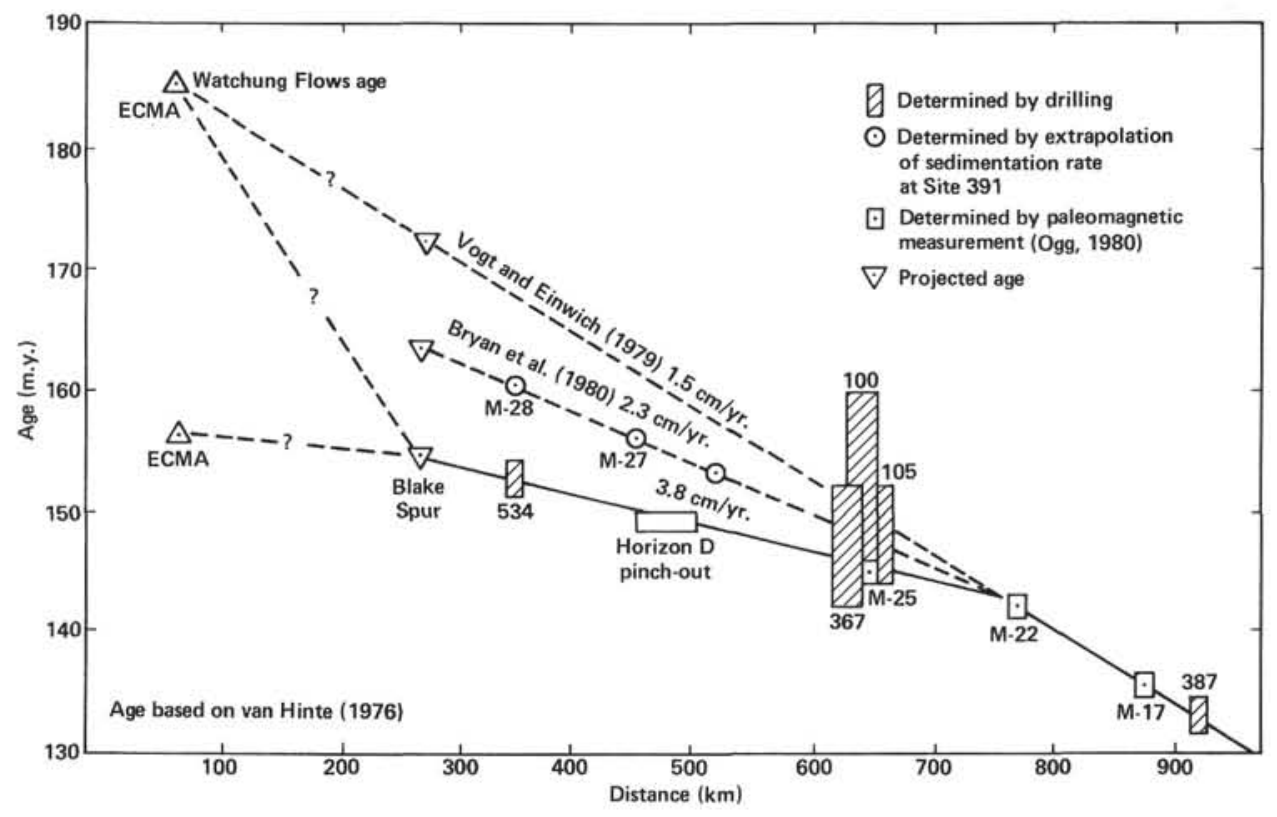

Figure 5. Plot of age versus distance for key magnetic anomalies with age correlations by various means. (Dashed lines are previous extrapolations and the solid line is the best determined age-distance curve. Position of East Coast magnetic anomaly [ECMA] is plotted as if its age is the same as the youngest Jurassic basaltic flows on the North American continent [Puffer et al., 1981]. This is an assumption that may not be true if the high spreading rates are assumed to apply to the ECMA-to-Blake Spur corridor as well.]

ing rate would project an age for the East Coast magnetic anomaly (ECMA) (Fig. 5) of approximately 185 m.y., which is about equal to the Hettangian to Pliensbachian age of the youngest massive basalt flows, such as the Watchung Flows (Puffer et al., 1981), in the rift basins exposed along the North American hinterland. If we assume that the basaltic extrusions back on the continent are the same event as the basaltic extrusions and intrusions forming the rocks of the ECMA, then this correlation makes sense. Using the Vogt and Einwich (1979) 
extrapolation of constant spreading from the M-25 and M-16 dates, the age of the Blake Spur anomaly would be about 175 m.y. on the van Hinte (1976) time scale.

Later, however, Bryan et al. (1980) used the extrapolation of sedimentation rates measured at Site 391 to project the age of the sediment thickness between the Cat Gap Formation at the bottom of 391 and the oceanic basement. This thickness was measured seismically and based on conversion of time to thickness using sonobuoy velocities at Site 534. The Bryan et al. (1980) extrapolation gave an age of $160 \mathrm{~m}$.y. for the basement at M-28 and an age of 156 m.y. or basal Callovian for Horizon D. Horizon D pinches out in the vicinity of M-27, providing another approximate date on these anomalies. These extrapolated ages would plot along a seafloor spreading-rate line with a rate of $2.3 \mathrm{~cm} / \mathrm{yr}$. (Fig. 5), which would still agree with the previous drilling on $\mathrm{M}-25$ and Sites 100 and 105. At these sites, long-ranging nannofossil zones date the basement as any age from Kimmeridgian to Oxfordian. This higher spreading rate of $2.3 \mathrm{~cm} / \mathrm{yr}$. for the quiet zone extrapolates to an age of $165 \mathrm{~m} . \mathrm{y}$. for the Blake Spur anomaly, quite a bit younger than had previously been published.

Now, however, the drilling at Site 534 dates basement as no older than middle Callovian, about 154 m.y., and Horizon D as early Oxfordian, about 149 m.y. on the van Hinte (1976) time scale. These points plot on a spreading-rate line (Fig. 5) that yields a spreading rate of $3.8 \mathrm{~cm} / \mathrm{yr}$. for the Jurassic quiet zone. This rate would still agree with the previous drilling on Anomalies M-25 (Sites 100 and 105) and M-16 (Site 387), but there must have been a drastic change in spreading rate about $\mathrm{M}-22$ time. Moreover, these age determinations for basement at M-28 and Horizon D yield projected ages of M-22 and M-25 that agree very well with the ages determined independently by Ogg (1980) by paleomagnetic measurements in the Tethyan stratigraphic section.

Thus the drilling and paleomagnetic evidence support a revision in the Jurassic paleomagnetic time scale, as proposed by Ogg (1980), and the occurrence of relatively high spreading in the Middle and Late Jurassic. The previous determinations by Vogt and Einwich (1979) were merely based on presumptions, which are apparently incorrect; and the extrapolations by Bryan et al. (1980), while on the right track towards younger dates, were based on imprecise sedimentation rates and sonobuoy velocities that could not give accurate predictions.

\section{IMPLICATIONS FOR NORTH AMERICAN MARGIN TECTONICS}

A very significant result of the drilling at Site 534 is the determination of the relatively fast Jurassic spreading, and if this rapid spreading is extrapolated to the Blake Spur magnetic anomaly, the age of this anomaly is now determined at 155 m.y., or early Callovian. Note that this age is now about $20 \mathrm{~m}$.y. younger than thought prior to drilling at Site 534 (Fig. 5). The Blake Spur anomaly is thought to represent an ocean crust formation event, probably extrusions of basalt, along the rift that signaled the formation of the modern North Atlantic. Prior to Blake Spur time a proto-type North Atlan- tic rift existed in the Blake Spur-East Coast magnetic anomaly corridor. Upon a major spreading-center shift to the Blake-Spur position, the proto-North Atlantic rift was isolated as an extinct rift, mostly on the North American plate side, as suggested by Vogt (1973), Sheridan (1978), and Klitgord and Behrendt (1979). Thus the Blake Spur anomaly marks a major tectonic event. As a general process of passive margin rifting, such spreading-center jumps are common in the early reorganization of drifting continents, and the Blake Spur event is typical of these.

Other supporting evidence for the spreading-center shift is the seismic reflection data across the Blake Spur anomaly; the seismic data reveal a buried ridge structure with a steep escarpment down-stepped on the west (Sheridan et al., this volume) (Fig. 6). This basement ridge runs continuously from the Blake-Bahama Basin to north of Cap Hatteras (Klitgord and Grow, 1980). Apparently on the basis of geophysical evidence (Sheridan et al., 1979), oceanic basaltic basement occurs on both sides of the structure. Of course, the drilling at Site 534 has proven the existence of normal oceanic basement in the outer magnetic quiet zone seaward of the Blake Spur, but no drilling has yet sampled basement in the inner magnetic quiet zone between the Blake Spur and East Coast magnetic anomalies. The Blake Spur basement escarpment could be explained by the possibility that basaltic crust of two different ages abutted, and the older crust in the inner magnetic quiet zone thermally cooled longer and therefore subsided more. The escarpment then marks an age discontinuity in the oceanic crust. This possibility would agree with the spreadingcenter shift hypothesis.

Note that Horizon D laps on the Blake Spur basement ridge from the west (Fig. 6), and in most cases the D to basement unit is trapped landward of the escarpment (Sheridan et al., this volume). Also note that the D to basement unit landward of the basement ridge is seismically stratified and could be formed of basin-leveling turbidites. Contemporaneous with these trapped turbidites, the contourites of the $\mathrm{D}$ to basement interval at Site 534 (Fig. 3) were made of hemipelagic clays that weak currents carried up on the then oceanic ridge, preferentially througb the deeper fracture-zone troughs. Eventıally in the early Oxfordian, the carbonate turbidites from the adjacent carbonate bank filled in the trough west of the Blake Spur ridge, and finally gained access to the basement trough at Site 534. From Horizon D time on, a continous, gentle slope of seafloor sediments then reached from the margin to the Site, and carbonate, terrigenous, and organoclastic turbidites were deposited sporadically there.

Thus dating Horizon D and basement at Site 534 helps us to date the Blake Spur rifting. Restoring the North Atlantic to the Blake Spur position (Fig. 7) in the basal Callovian indicates that most of the North Atlantic Ocean was closed. Only the proto-North Atlantic along the North American margin was extant. The age of this proto-Atlantic rift is now open to question. All that is known is that it is older than early Callovian ( 155 m.y.) and younger than Pliensbachian (185 m.y.). It is possi- 
NE

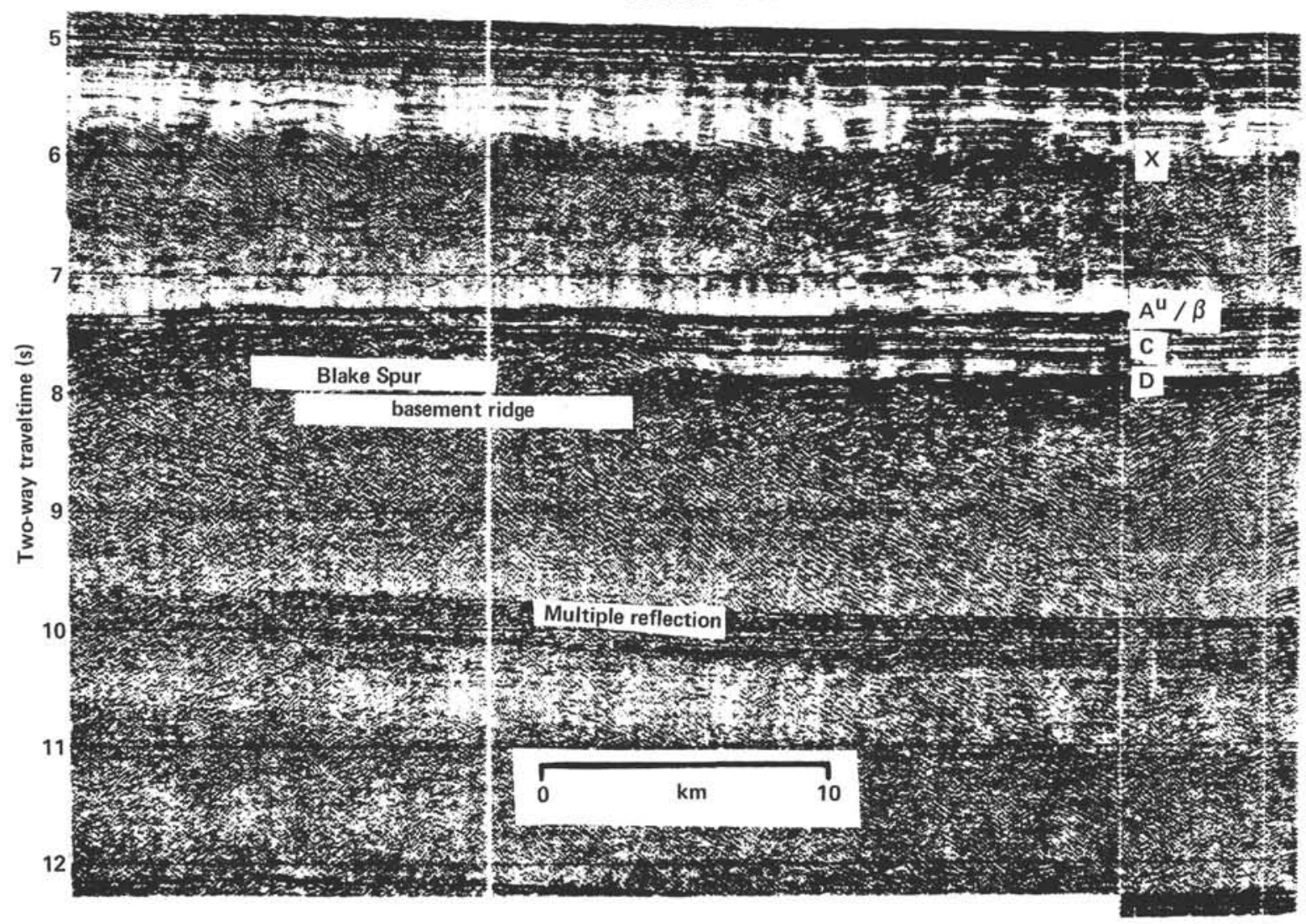

Figure 6. Multichannel seismic reflection profile showing the Blake Spur basement ridge and down-stepped escarpment against which the Horizon D to basement interval onlaps.

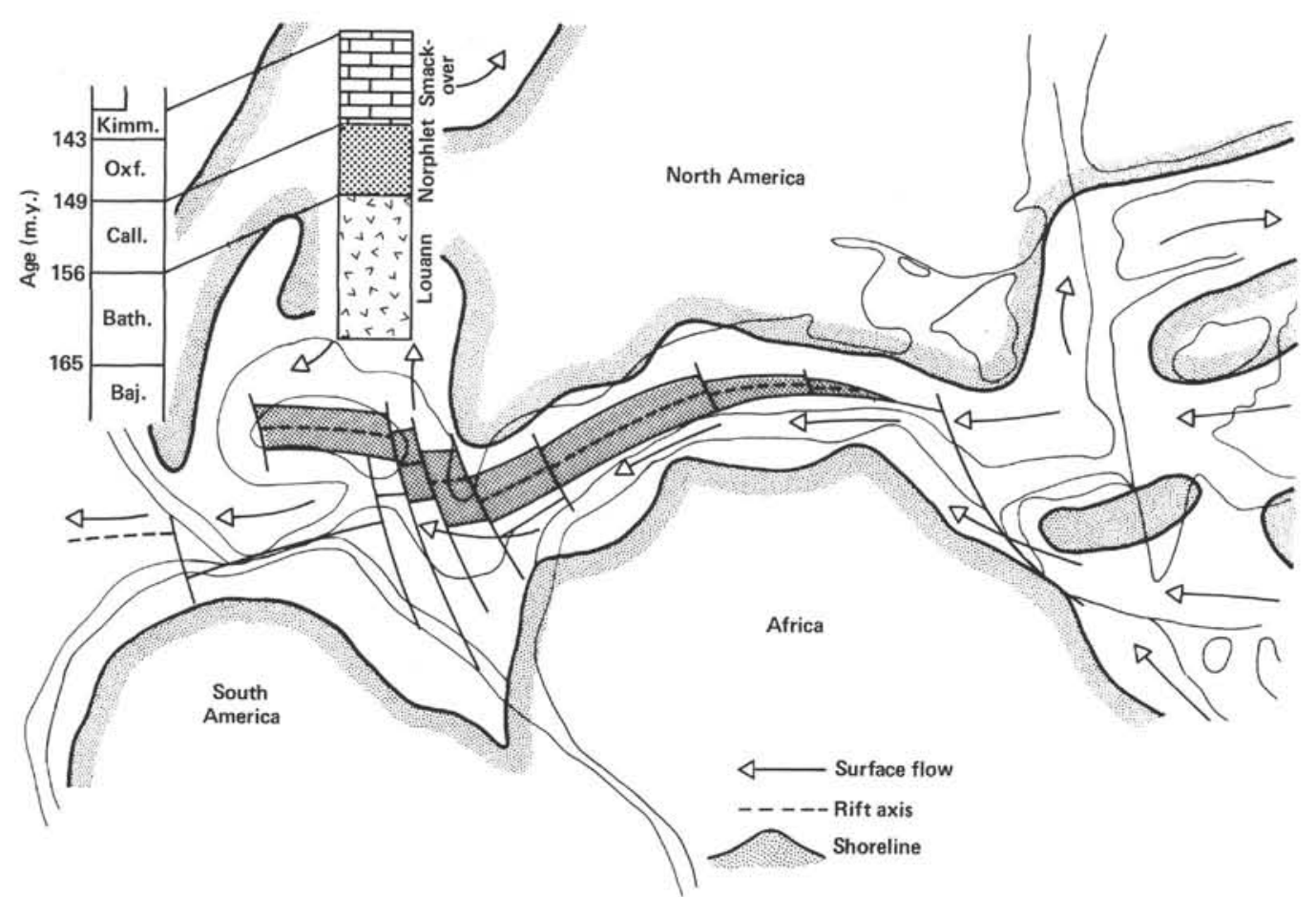

Figure 7. Continental reconstruction and paleogeography at Blake Spur magnetic anomaly time, approximately $155 \mathrm{Ma}$, or basal Callovian (van Hinte, 1976, time scale). (Land areas are shown in contrast to epicontinental seaways. The proto-North Atlantic rift along the eastern North American continental margin and Gulf of Mexico is also shown. Surface currents probably flowed from the European Tethys through the Atlantic to the Pacific, from east to west, driven by the near equatorial trade winds [Ager, 1975].) 
ble, however, that it is quite young, if we accept the extrapolation of the high Jurassic spreading rates landward of the Blake Spur. Could it be that the proto-Atlantic rift formed as recently as the late Bathonian and spread extremely rapidly? This, I believe, is not contradicted by existing data.

In fact, the biogeographic evidence suggested to Hallam (1977) that the central North Atlantic did not begin oceanic spreading until after the early Callovian. Only after this time (155 Ma) did certain ammonite patterns indicate a deep ocean connection between the Pacific and Tethys. Hallam (1977), therefore, was one of the first researchers to suggest a relatively late opening for the North Atlantic.

Barrett and Keen (1975) also noted that possibility of a younger age of opening for the North Atlantic. They noted that, on the basis of the North American polar wander curve, Steiner (1975) requires a relatively high spreading rate in the Late Jurassic Atlantic: the fit of the curve requires a 4 to $4.5 \mathrm{~cm} / \mathrm{yr}$. rate and a breakup 157 m.y. ago.

Such a late stage opening is necessary to spread a small ocean basin in the Gulf of Mexico, which is proposed to separate the syn-rift Louann salt deposits (Salvador and Green, 1980) (Fig. 7). It is possible that the proto-Atlantic rift was the same age as and continuous with the Gulf of Mexico rift. The spreading-center shift needed to isolate the Gulf of Mexico with the North American plate by shifting the center of oceanic rifting to the southeast margin of Yucatan could have occurred in basal Callovian, just about the same time as the Blake Spur jump. Maybe these are one and the same event.
With the evidence for rapid spreading in the Late Jurassic, after the Blake Spur rift breakup, the North Atlantic opened $750 \mathrm{~km}$ in $10 \mathrm{~m}$.y. so that by mid-Oxfordian, about the time of Anomaly M-26, there was already a deep, wide ocean basin (Fig. 8). Note that this Jurassic opening along a rift on the southeast Yucatan margin will allow for a Jurassic oceanic crust in the Caribbean, where recently Jurassic ophiolites have been reported (Biju-Duval et al., 1981).

From the drilling at Site 534, the evidence indicates that normal hemipelagic and pelagic deposition on a bare oceanic basement prevailed in the Callovian-early Oxfordian. Also the evidence for bottom-water circulation and contourites indicates a complicated oceanic circulation. Probably the rapid opening of the North Atlantic caused a more complicated surface current flow, with perhaps counter-flow in the near equatorial Tethys ocean. Prior to the Callovian, the narrow proto-Atlantic may have constrained flow to unidirectional westward transport from the European Tethys to the Pacific (Ager, 1975), following the prevailing trade winds. Then the abrupt opening in the Callovian-Oxfordian created complications that possibly stimulated bottom flow, divergences, and upwelling. This event could explain the abundant radiolarians in the Callovian-Oxfordian rocks all over the Tethys that produced the red and green ribbon cherts in some areas.

The geologic history portrayed here fits the oceanic drilling and geophysical data well. It should be pointed out in support of this new timing of the North Atlantic breakup that the continental stratigraphy indicates a tremendous, abrupt transgression in the latest Bathonian-

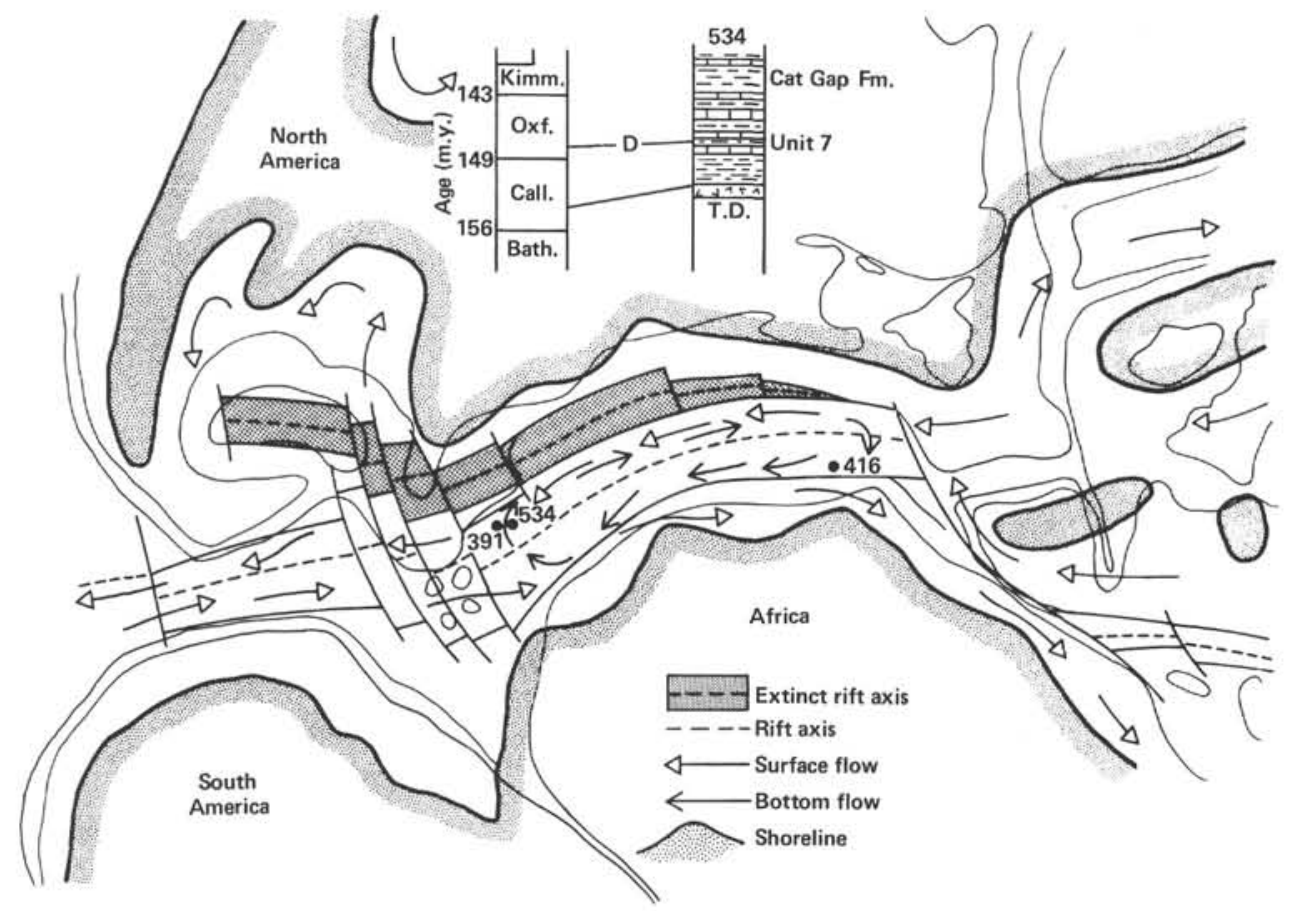

Figure 8. Continental reconstruction and paleogeography at the time of Magnetic Anomaly M-26, approximately $145 \mathrm{Ma}$, or mid-Oxfordian (van Hinte, 1976, time scale). The extinct proto-Atlantic rift had been isolated on the North American plate, and Jurassic ocean crust formed from the Caribbean to the Grand Banks. Bottom currents circulated as contour-following flow around the mid-ocean ridge topography, especially through fracture zones such as at Site 534.) 
earliest Callovian through the Oxfordian. Deposition of the Cornbrash Formation in England and the Sundance Formation in Wyoming are evidence of these widespread Late Jurassic seas invading the continental interior. Hallam (1975) notes this worldwide Late Jurassic sealevel rise. The combined effect of abrupt subsidence around the North Atlantic at breakup as the oceanic lithosphere rapidly cooled, and the ocean volume reduction by the rapid spreading pulse producing a shallow mid-ocean ridge, led to a major marine invasion. This eustatic event signaled the time of opening of the central North Atlantic.

\section{IMPLICATIONS FOR GLOBAL PROCESSES, PULSATION TECTONICS, AND ORIGIN OF THE FIRST ORDER GEOCYCLES}

Values for the Late Jurassic spreading rates of 3.8 $\mathrm{cm} / \mathrm{yr}$. are comparable to those determined most recently for the middle Cretaceous when fast spreading occured in all the world's oceans. With the latest paleomagnetic measurements revising the ages of Anomaly 34 on the young side of the Cretaceous magnetic quiet zone and Anomaly M-0 on the old side (Lowrie et al., 1980), there is a reaffirmation that the spreading rate was as much as $100 \%$ higher than at present, even though these revisions allow about $10 \%$ more time for the quiet zone to spread. Thus for the Cretaceous, both the quiescence of the magnetic field and the high spreading rates of plate motions are global phenomena.

As for the Jurassic magnetic quiet zones, the occurrence of these at approximately the same time in both the North Atlantic and Pacific oceans, in crusts with vastly different absolute spreading rates, seems proof enough that this Jurassic magnetic quiet period too was a global field phenomenon. A real quiescence of the Earth's magnetic field must have occurred, but whether this was due to a lack of reversals or a decrease in strength of the field, or both, is still uncertain (Steiner, 1980). Other explanations of the Jurassic quiet zones related to their being adjacent to the North American and African continents would not explain the Jurassic quiet zone in the Pacific, which just recently spread into that position next to the trenches. Thermal alteration of the magnetic minerals by sediment burial is a possible explanation that has been reviewed by Taylor et al. (1968) and Barrett and Keen (1975). However, during the Late Jurassic, the Pacific Ocean was the huge ancient ocean in contact with the Tethyan Seaway, and the Atlantic was approximately $750 \mathrm{~km}$ wide (Fig. 8). In this relatively wide Atlantic Ocean, currents circulated to keep the basement temporarily clean of sediment and only pelagic, hemipelagic, and distal turbidites were eventually deposited. Such an environment is not conducive to thermal alteration by sediment burial, as is presently taking place in the Gulf of California where there is extremely rapid sedimentation (Moore and Curray, 1982). The basalt recovered at Site 534 was typical oceanic pillow basalt without thick intercalations. It is well magnetized with a normal Jurassic polarization (Site 534 report, this volume). In short, we cannot appeal to processes to remove the magnetization from the quiet zone rocks or to unusual kinds of rocks.
Because the Jurassic magnetic quiet period is a global phenomenon, then by analogy to the Cretaceous quiet zone, the high spreading rate in the Atlantic very likely reflects global occurrences of high spreading rates in the other Jurassic oceans. The most that can be said, given the new ages for the M-25 and older anomalies presented here, is that relatively high spreading rates occurred in the Jurassic western North Atlantic, the eastern North Atlantic, and in the Jurassic western Pacific Ocean. By inference there are these two correlative occurrences of fast seafloor spreading and relative quiescence of the Earth's magnetic field; one in the mid-Cretaceous and one in the Middle and Late Jurassic (Fig. 9). Although there are only these two occurrences of quiet zones for study in the modern oceans, there are several other magnetic quiet times documented by paleomagnetic measurements on land, such as the constant negative polarity of the Permian Kiaman Interval. It would be convenient to be able to extrapolate into the past and infer that during these ancient magnetic quiet times, the now missing oceanic basement was being spread very rapidly towards the continents and into subduction zones where it has since disappeared.

Plots of the spreading rates for the central North Atlantic just south of the Kane fracture zone along a flow line near Site 534 were constructed (Fig. 9). Using the mapped magnetic anomaly positions and the dates of Lowrie et al. (1980) and Ogg (1980) for the Jurassic, Cretaceous, and Tertiary reversals, the spreading rates were calculated. Also plotted (Fig. 9) were the calculated number of apparent magnetic reversals (recorded as seafloor anomalies) per time for each spreading episode. The two correlative events of high spreading rates and low apparent magnetic reversal frequency in Late Jurassic and mid-Cretaceous are evident.

What is the possible cause of this correlation? Obviously the origin of the magnetic field of the Earth and the processes causing its reversal are found in the liquid outer core, whereas the origin of plate motions and their velocities are controlled by the properties and stresses in the lithosphere and asthenosphere. Yet these two changes are related in some way. This correlation leads to a very intriguing question. Does the outer core influence the mantle or does the mantle influence the outer core?

Vogt (1975) noted this relationship between plate tectonic changes and magnetic field changes and hypothesized that events such as plume eruptions from the lower mantle could effect both the core/mantle boundary and the overlying asthenosphere (Fig. 10). He noted that the phase lag, $\Delta t$, between changes in the magnetic field, which should occur first, and the subsequent plate tectonic effects was evidence that deep lower mantle processes such as plumes were involved. The observational data (Fig. 9) appear to document this phase lag where the high spreading-rate episodes extend into the Early Cretaceous and Latest Cretaceous/earliest Tertiary as much as $10 \mathrm{~m} . \mathrm{y}$. after magnetic reversals began to increase in frequency.

Besides this circumstantial evidence, other theoretical aspects support this hypothesis. For example, Doell and Cox (1972) note that properties of the lower mantle can affect the magnetic field. They liken the core/mantle 


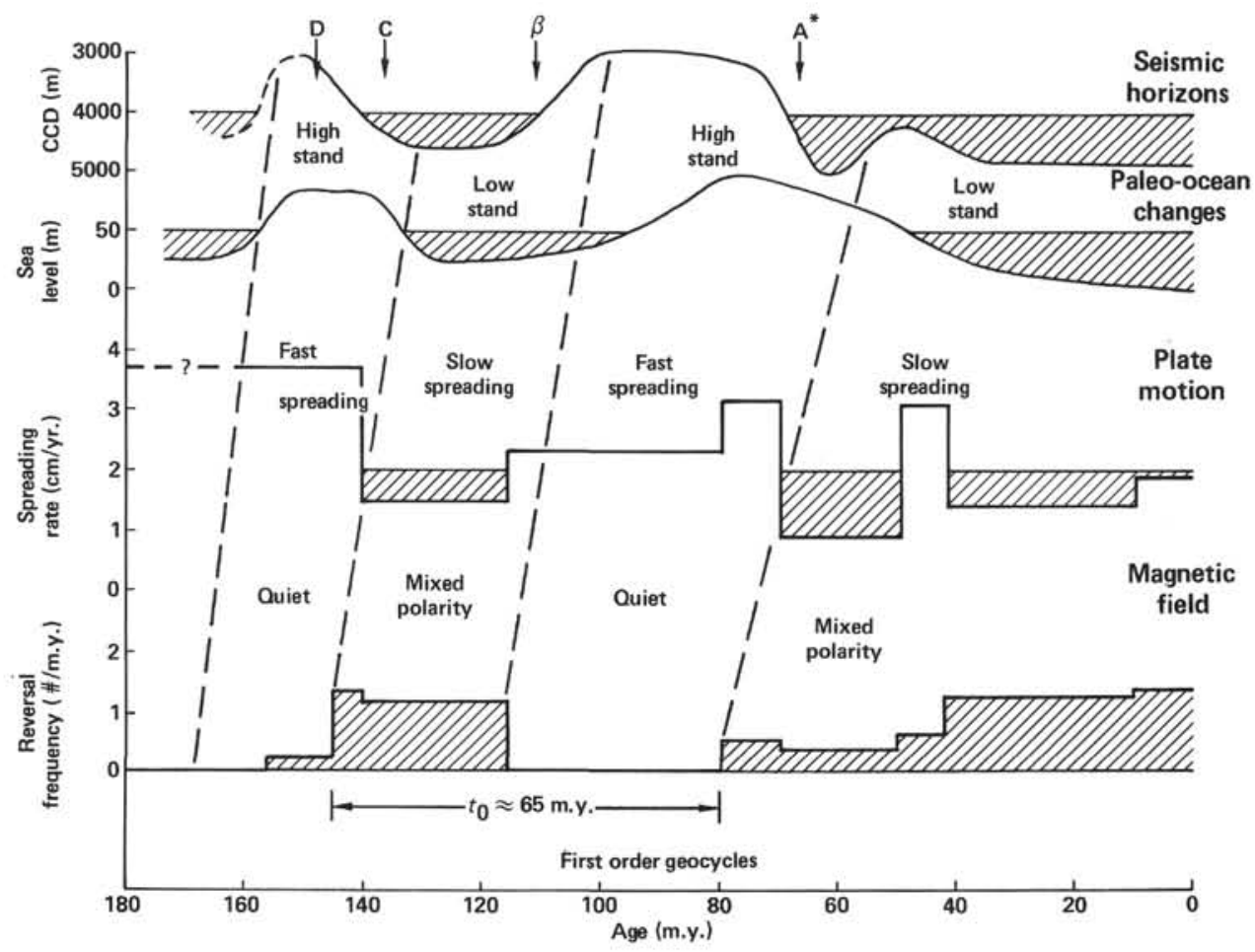

Figure 9. Time-correlation diagram showing the correlation between the western North Atlantic spreading rates for the flow-line through Site 534 and the magnetic reversal frequency for the same time intervals, the estimates of eustatic sea-level rise (Watts and Steckler, 1979; Hallam, 1975), and the rise and fall of the calcium carbonate compensation depth (CCD) (Jansa et al., 1979). (Also indicated are the ages of the key seismic reflection Horizons $A^{*}, \beta, C$, and D.)

boundary to the surface of the Earth with solid rock in contact with a hot convecting fluid. If the temperature at the interface is greater, the core convection at the interface is more turbulent or "stormier." If the temperature is less, the convection is smoother and more laminar. In the former "stormier" case, the Earth's magnetic field measured at the surface should be more dipolar and strong, but inherently less stable; whereas a more stable, but weaker, toroidal field should result in the latter case (Strangway, 1970). The interplay between the toroidal and dipolar components of the field are critical for the maintenance of the Earth's magnetic field at the surface. Whatever the cause of the heat in the core that maintains the turbulent convection, be it radiogenic, geochemical, or rotational, conditions at the core/mantle boundary can affect this heat.

Changes in temperature of a significant amount $\left(\sim 100^{\circ}-200^{\circ} \mathrm{C}\right)$ in a few tens of millions of years at the core/mantle boundary might explain the observational changes in the magnetic field, as indicated by Jones (1977) (Fig. 10). There are only a few thermal processes and mechanisms that could produce such changes. Examining the general heat-flow equation for temperature within a moving material:

$$
\frac{\delta T}{\delta t}=\frac{k}{\varrho c} \frac{\delta^{2} T}{\delta z^{2}}+\frac{A}{\varrho c}-v \frac{\delta T}{\delta z}
$$

the rate of temperature change controlled by the first two terms, via conduction and radiogenic heat over man- tle-wide depths, is very slow, $\sim 100^{\circ} \mathrm{C} /$ billions of years. In equation (1), $T$ is temperature, $z$ is depth, $k$ is thermal conductivity, $\varrho$ is density, $c$ is heat capacity, and $A$ is heat generation. However, the convective heat transfer term could cause significant temperature changes over a few million years, if the velocity of mantle-plume convection is large enough.

For vertical thermal convection in a spherically symmetric Earth, the heat-flow equation can be simplified to:

$$
\frac{\delta T}{\delta t} \approx-v \frac{\delta T}{\delta z}
$$

in which $v$ is the convection velocity away from higher temperatures. A generalized solution to this equation would reflect the change in temperature in the convective medium of the mantle, which will vary with time as the convecting hot material passes a certain depth. The oscillatory nature of this solution reflects the circulation of the convection cell, first heating then cooling, then heating again as the flow of hot mantle completes its circulation from one cycle to the next. The period of the cycle is determined by the equation:

$$
t_{0} \approx \frac{L}{v}
$$

where $L$ is the path length of material moving in the convection cell. 


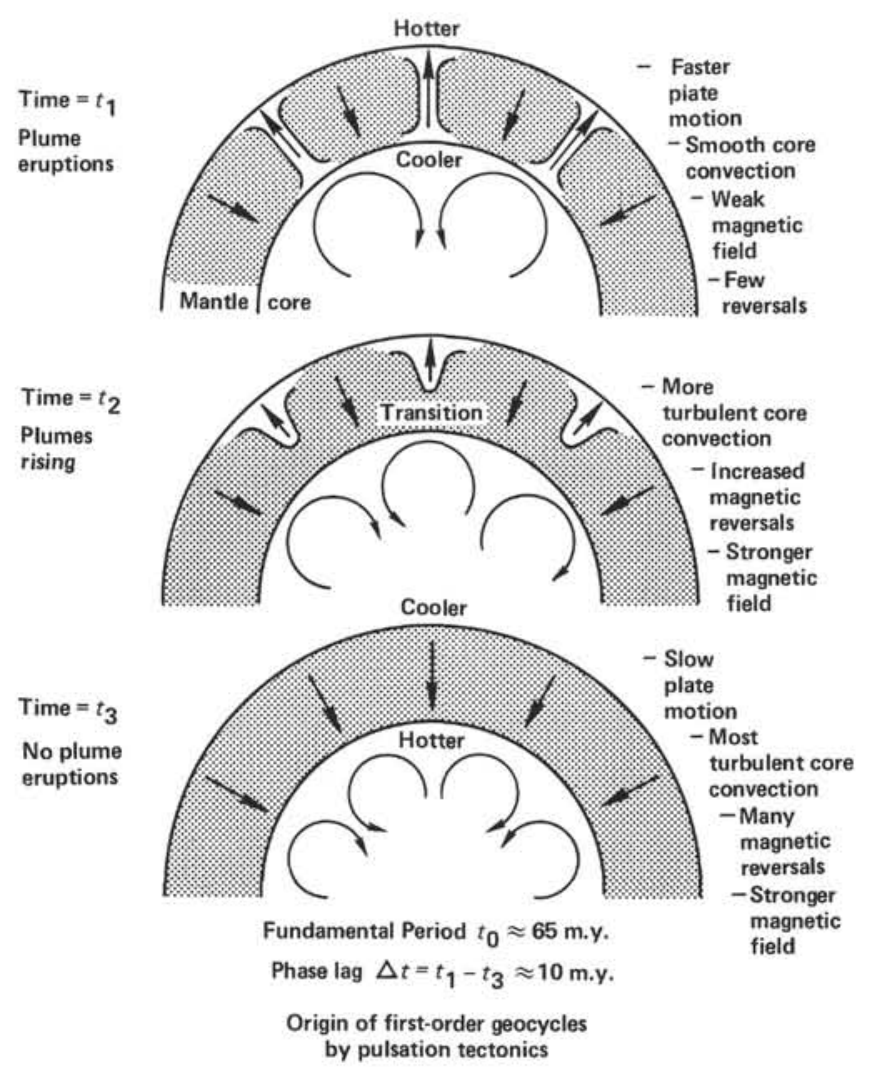

Figure 10. Diagrammatic model of pulsation tectonics involving cyclic eruptions of plumes of hot mantle material circulating from the lowermost mantle to the asthenosphere (after Vogt, 1975; Jones, 1977). (The phase lag, $\Delta t$, is controlled by the rise time of the plumes, and the fundamental period of the geocycles, $t_{0}$, is controlled by the velocity of convection along the path of the plumes and the thermal transfer time required to heat the lowermost $\mathrm{D}^{\prime \prime}$ layer of the mantle for instability.)

For the lower mantle-wide convection of plumes erupting from the lower mantle and rising to the asthenosphere, with cooler mantle material sinking to the lower mantle, as envisioned by Vogt (1975), the size of the convection cell path, $L$, would be about $\Pi$ times the diameter of the cell, the diameter being approximately $2200 \mathrm{~km}$. Therefore $L \approx 6900 \mathrm{~km}$ in equation (3). If the velocity of convection were known, then the period of plume circulation could be calculated.

Plume convection velocities are controlled by the temperature difference relative to the ambient temperature in the lower mantle, $\Delta T$, and by the viscosity, $\xi$, of the mantle rock (Yuen and Schubert, 1976). This relationship can be derived from the basic equation balancing the viscous forces that resist flow with the buoyancy forces, which cause the plume to rise:

$$
\frac{\partial}{\partial y} \xi(T) \frac{\partial v}{\partial y}=g \varrho \alpha \Delta T
$$

where $\alpha=$ the coefficient of thermal expansion over a plume of dimension $y$, and $g$ is the acceleration of gravity. Yuen and Schubert (1976), who have studied the physics of mantle plumes, conclude that:
If thermal anomalies can arise in the mantle as a result of chemical heterogeneity, for example, then the rheological behavior of the mantle material is such that narrow plumes can rise hundreds of kilometers through the mantle at velocities between one and several tens of centimeters per year even for a temperature difference between the plume and ambient mantle as low as $100^{\circ} \mathrm{C}$.

Also, in similar analyses of plume behavior, Yuen and Peltier (1980) find that:

Because of the strong temperature dependence of mantle viscosity, ... [the lowermost $\mathrm{D}^{\prime \prime}$ layer of the mantle] could be strongly unstable against secondary convective instability. Linear stability analyses... show that this destabilization is in fact dramatic, the fastest growing disturbances being characterized by growth times on the order of $10^{6}$ years and spatial scales on the order of $10^{2} \mathrm{~km}$ for a wide variety of plausible lower mantle conditions.

Such plume eruptions will have the effect of taking heat rapidly from the lower mantle to the asthenosphere (Jones, 1977) (Fig. 10). In the asthenosphere partial melting will cause widespread volcanism and hot-spot development through the lithosphere, such as happened in the Pacific in the mid-Cretaceous (Larson and Schlanger, 1981). The net effect of the plume eruptions will be to speed up plate motions by possibly forcing plates apart and by decreasing the asthenosphere's viscosity, allowing the plates to descend more quickly in subduction and to move more rapidly in response to a given set of boundary forces on the plate edges. The phase lag between initiation and cessation of plume eruptions in the lower mantle, which will quickly change the magnetic field, is caused by the time it takes for plumes to rise through the lower mantle convection process (Vogt, 1975). This leads to a basic asymmetry or phase lag, $\Delta t$, in the cycle. During a period of a cycle the asthenosphere is hotter while the outer core is being cooled down, and the asthenosphere is cooler while the outer core is heating up (Fig. 10). A phase lag of the order of $\Delta t \approx$ 10 m.y., (Fig. 9) is in agreement with convection velocities of $10 \mathrm{~cm} / \mathrm{yr}$., which is the same order of magnitude than Yuen and Schubert (1976) determined for the velocities of plumes. When applying the velocities of $10 \mathrm{~cm} / \mathrm{yr}$. in equation (3) for lower mantle-wide convection, the period of these plume eruption cycles is calculated as $69 \mathrm{~m} . y$. This calculation agrees reasonably well with the observations of these first-order geocycles of changing magnetic field and plate spreading phenomena (Fig. 9).

After the plume eruptions occur and take heat rapidly away from the core/mantle boundary, the descending cooler mantle material stabilizes the lower mantle. Then via conduction the heat confined to the molten core begins again to affect the lower mantle, and temperatures at the core/mantle boundary begin to rise (Jones, 1977). The amount of time required for this temperature buildup and for eventual instability in the lower mantle can 
be calculated from the one-dimensional heat-conduction equation. For the particular position in the center of the layer of $H$ thickness, the thermal transfer time, $t_{1 / 2}$, to reach half of the new equilibrium temperature caused by a temperature disturbance of $T_{0}$ above ambient temperature would be given by:

$$
t_{1 / 2} \approx 0.693 \frac{H^{2}}{\Pi^{2}} \frac{\varrho c}{K} .
$$

For a layer thickness of $H=100 \mathrm{~km}$ in the lowermost part of the mantle, the time needed to raise the temperature several hundred degrees above ambient would be the order of several tens of millions of years, if reasonable values of density, $\varrho$, heat capacity, $c$, and conductivity, $K$, are assumed. This time, the thermal transfer time, $t_{1 / 2}$, will also control the periodicity of the plume eruption cycles, as does their convection velocity and time needed to circulate throughout the lower mantle, $t_{0}$. All these theoretical considerations seem to indicate that lower mantle-wide convection is possible with plume mechanisms and that the periods of the cycles of plume eruptions are 60 to 100 m.y. (Fig. 10).

It should be noted that the high spreading rate pulses apparently occurred just at the time when major continental breakup of Pangaea occurred: the central North Atlantic, southeast Africa, and western Australian margins in mid-Jurassic; the central South Atlantic and southern Australian margins in mid-Cretaceous; the Norwegian Sea in Paleocene-Eocene, for example. From this a corollary might be stated: all rifted oceans originate with pulses of fast spreading. Plume eruptions and hot spots have long been called on as a means of rifting continents. Maybe this really is an important mechanism. In support of this hypothesis a plot of the length of the rifts versus the age of the Pangaea margins shows that most of the breakup took place during the times of global fast plate spreading (Fig. 11).

Another far-reaching implication of this hypothesis of cyclic pulsations via plume eruptions is that the faster-spreading episodes will result in eustatic sea-level rise (Pitman, 1978; Vail et al., 1977). The estimates of the magnitude of these sea-level variations vary (Watts and Steckler, 1979), but amplitudes of approximately $100 \mathrm{~m}$ are acceptable to most researchers. Also, most researches detect two high stands of eustatic sea-level in the last $180 \mathrm{~m} . y$. , one in the mid-Cretaceous and one in the Late Jurassic (Hallam, 1975) (Fig. 9). These are the first-order global sea-level megacycles of Vail et al. (1977).

Associated with these major eustatic sea-level rises are fluctuations in the calcium carbonate compensation depth, CCD (Fig. 9). Several authors have noted this variation and correlation with sea level (Sclater et al., 1979; Berger, 1979), but the causal relationship between sea level and CCD variation is not well known. Factors such as the trapping of carbonate in estuaries, changes in global climate, forestation, changes in albedo, and resulting changes in atmospheric $\mathrm{CO}_{2}$ are all involved (Berger, 1979). Most factors, however, favor a shallowing of the CCD during higher sea-level stands (Fig. 9).

The most important thing is that this hypothesis of pulsation tectonics, which originates in the core of the

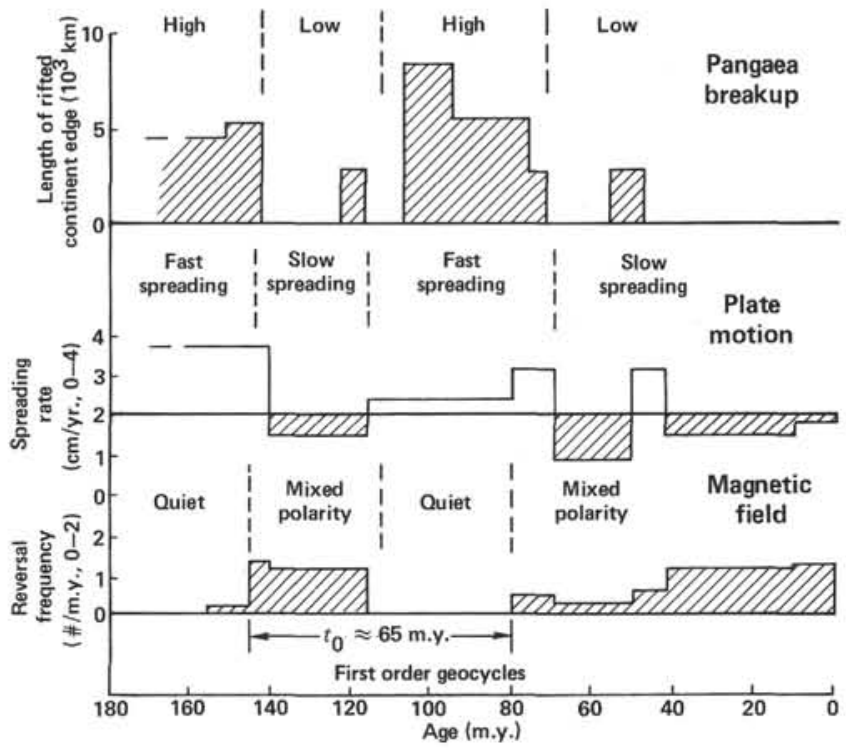

Figure 11. Plot of length of rifted margins of Pangaea versus age of breakup. (This plot indicates that pulses of breakup occurred during the global pulses of fast plate spreading.)

Earth, has a first-order impact on the controls of the paleoceanographic environment. Paleobathymetric changes occur with global spreading rate changes, new oceans open with plume eruptions of hot spots, and sea levels rise and fall as mid-ocean ridges grow faster or slower, and finally the very chemical composition of the world's oceans is influenced. This gross systems analysis of the Earth provides a working model to understand the long period cycles, $t_{0} \approx 65 \mathrm{~m}$.y., of the entire environment. It forms a strong predictive tool with which to go backward in time to perhaps understand how the Earth worked even when the oceanic record has been totally destroyed in subduction. The term pulsation tectonics is appropriate following the pulsation theory of Umbgrove (1947), which described a tectono-eustatic origin for stratigraphic cycles.

On a more local scale, such as the North American basin of the western North Atlantic, the variation of CCD predicted in this model (Fig. 12) seems to have controlled the interbedded shale and limestone formations drilled by DSDP at several sites, including Site 534 . The boundaries between these formations are the strong acoustic impedance contrasts that cause the basinwide seismic reflectors such as $\beta, \mathrm{C}$, and D (Sheridan et al., this volume). At Site 534 in the oldest claystone unit just above basement, the carbonate content drops so low that it can be inferred that the CCD was above the seafloor at that time. This is the first evidence for the Jurassic cycle of CCD rise that should be associated with the Jurassic sea-level rise.

\section{SUMMARY AND CONCLUSIONS}

1. The breakup associated with the Blake Spur magnetic anomaly, which led to the modern North Atlantic Ocean, occurred in basal Callovian, about $155 \mathrm{Ma}$.

2. Possibly the proto-Atlantic rift between the East Coast magnetic anomaly and the Blake Spur anomaly is 


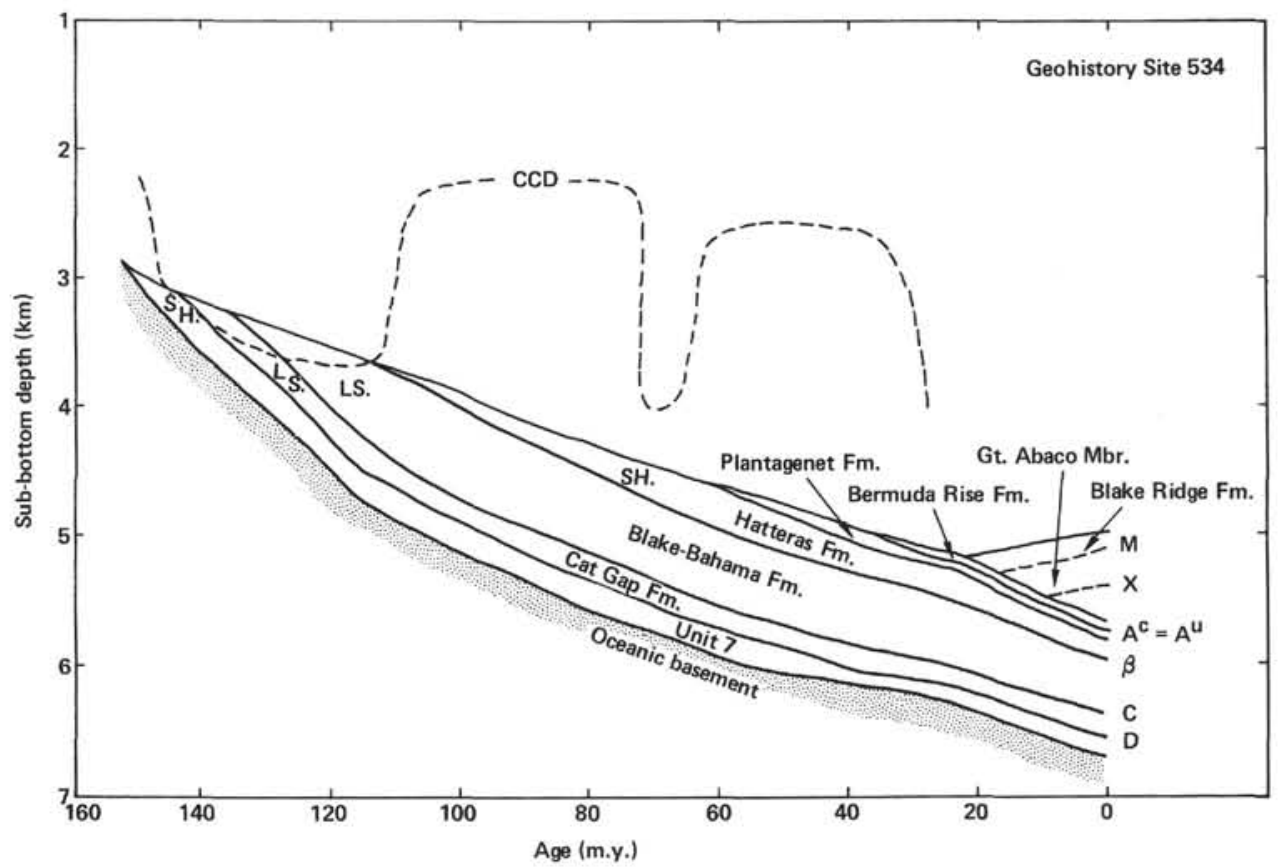

Figure 12. Geohistory of Site 534 corrected for thermal subsidence, sediment loading, and sediment compaction. (Superimposed on the plotted paleobathymetry is the fluctuating CCD curve [Jansa et al., 1979] for the western North Atlantic. The impact of CCD on the seafloor controls the shale versus limestone lithofacies of the basin formations, and these boundaries form the key seismic reflectors $\beta$, C, and D. LS. = limestone; SH. = shale.)

equivalent in age to the oceanic rift in the center of the Gulf of Mexico.

3. Spreading rates of $3.8 \mathrm{~cm} / \mathrm{yr}$., which are quite high, are found for the Middle through Late Jurassic oceanic crust of the North Atlantic.

4. High spreading rates for the lithospheric plates correlate in time with times of quiescences of the Earth's magnetic field.

5. The association of fast spreading with quiet magnetic fields agrees with the theory of pulsation tectonics in which plumes emanating from the lowermost mantle affect both the temperature at the core/mantle boundary and later the asthenosphere and lithosphere.

6 . The theory of pulsation tectonics explains the firstorder geocycles reflected in megacycles of sea-level changes and $C C D$ variations.

7. There is some suggestion that the global pulses of rapid spreading, related to plume eruptions, also correlate with the breakup of major rift ocean basins.

8. The CCD variations control the carbonate-shale facies in the western North Atlantic basin and, therefore, the major seismic reflection Horizons, such as $\beta$, $\mathrm{C}$, and D, which are found at or near lithofacies formation boundaries.

\section{ACKNOWLEDGMENTS}

The author thanks the National Science Foundation and JOI Incorporated for various grants and contracts related to the collection and interpretation of geophysical data presented here. I thank the officers and crews for their assistance during cruises aboard the Eastward and Robert Conrad. Much credit goes to the planning panels of JOIDES and the technical staff of the Deep Sea Drilling Project, and to the marine and drilling crew of the Glomar Challenger for their high performance in achieving the scientific objectives of Leg 76 . Funding for release-time for work on the Glomar Challenger was provided by the Deep Sea Drilling Project. This manuscript was reviewed by P. Vogt, K. Klitgord, J. Heirtzler, and D. Yuen.

\section{REFERENCES}

Ager, D. V., 1975. The Jurassic World Ocean (with special reference to the North Atlantic). Jurassic Northern North Sea Symposium, Stavanger.

Barrett, D. L., and Keen, C. E., 1975. Mesozoic magnetic lineations, the magnetic quiet zone, and sea-floor spreading in the Northwest Atlantic. J. Geophys. Res., 81:4875-4884.

Berger, W. H., 1979. Impact of deep sea drilling on paleoceanography. In Talwani, M., Hay, W., and Ryan, W. B. F. (Eds.), Deep Drilling Results in the Atlantic Ocean: Continental Margins and Paleoenvironment. Am. Geophys. Union, Maurice Ewing Series, 3: 297-314.

Biju-Duval, B., Mascle, A., Rosales, H., and Young, G., 1981. Geological and geophysical sections through the North Venezuelan margin. Hedberg Research Conference, Continental Margin Processes, Galveston, Texas, pp. 9-10. (Program with Abstracts)

Bryan, G. M., Markl, R. G., and Sheridan, R. E., 1980. IPOD site surveys in the Blake-Bahama Basin. Mar. Geol., 35:43-63.

Cande, S., Larson, R., and La Brecque, J., 1978. Magnetic lineations in the Pacific Jurassic Quiet Zone. Earth Planet. Sci. Lett., 41: 434-440.

Doell, R. E., and Cox, A., 1972. The Pacific geomagnetic secular variation anomaly and the question of lateral uniformity in the lower mantle. In Robertson, E. C., Hays, J. F., and Knopoff, L. (Eds.), The Nature of the Solid Earth: New York (McGraw-Hill), pp. 245-284.

Hallam, A., 1975. Jurassic Environments: New York (Cambridge Univ. Press).

1977. Biogeographic evidence bearing on the creation of Atlantic seaways in the Jurassic. In West, R. M. (Ed.), Paleontology and Plate Tectonics. Milwaukee Public Museum, Spec. Publ. in Biology and Geology, 2:23-39.

Jansa, L., Enos, P., Tucholke, B. E., Gradstein, F. M., and Sheridan, R. E., 1979. Mesozoic and Cenozoic sedimentary formations of 
the North American Basin; western North Atlantic. In Talwani, M., Hay, W., and Ryan, W. B. F. (Eds.), Deep Drilling Results in the Atlantic Ocean: Continental Margins and Paleoenvironment. Am. Geophys. Union, Maurice Ewing Series, 3:1-57.

Jones, G. M., 1977. Thermal interaction of the core and mantle and long-term behavior of the geomagnetic fields. J. Geophys. Res. 82:1703-1709.

Klitgord, K. D., and Behrendt, J. C., 1979. Basin structure of the U.S. Atlantic Margin. Am. Assoc. Pet. Geol. Mem., 29:85-112.

Klitgord, K. D., and Grow, J. A., 1980. Jurassic seismic stratigraphy and basement structure of the western Atlantic magnetic quiet zone. Am. Assoc. Pet. Geol. Bull., 64:1658-1680.

Larson, R. L., and Schlanger, S. O., 1981. Cretaceous volcanism and Jurassic magnetic anomalies in the Nauru Basin, western Pacific Ocean. Geology, 9:480-484.

Lowrie, W., Chanell, J. E. T., and Alvarez, W., 1980. A review of magnetic stratigraphy investigations in Cretaceous pelagic carbonate rocks. J. Geophys. Res., 85:3597-3605.

Moore, D. G., and Curray, J. R., 1982. Geologic and tectonic history of the Gulf of California. In Curray, J. R., Moore, D. G., et al., Init. Repts. DSDP, 64, Pt. 2: Washington (U.S. Govt. Printing Office), 1279-1295.

Ogg, J., 1980. Upper Jurassic magnetostratigraphy from northern Italy. EOS Trans., Am. Geophys. Union, 61:216.

Pitman, W. C., III., 1978. Relationships Between eustasy and stratigraphic sequences on passive continental margins. Geol. Soc. Am. Bull., 89:1389-1403.

Puffer, J. H., Hurtubise, D. O., Geiger, F. J., and Lechler, P., 1981. Chemical composition and stratigraphic correlation of Mesozoic basalt units of the Newark Basin, New Jersey, and the Hartford Basin, Connecticut: summary. Geol. Soc. Am. Bull., 92(pt. 1): 155-159.

Salvador, A., and Green, A. R., 1980. Opening of the Caribbean Tethys (origin and development of the Caribbean and Gulf of Mexico). Geology of the Alpine Chains Born of the Tethys, Colloque C5, Mem. BRGM, 115:224-229.

Sclater, J. G., Boyle, E., and Edmond, J. M., 1979. A quantitative analysis of some factors affecting carbonate sedimentation in the oceans. In Talwani, M., Hay, W., and Ryan, W. B. F. (Eds.), Deep Drilling Results in the Atlantic Ocean: Continental Margins and Paleoenvironment. Am. Geophys. Union, Maurice Ewing Series, $3: 235-248$.

Sheridan, R. E., 1978. Structural and stratigraphic evolution and petroleum potential of the Blake Plateau. Offshore Tech. Conf. Proc., pp. 363-368.
Sheridan, R. E., Grow, G. A., Behrendt, J. C., and Bayer, K. C., 1979. Seismic refraction study of the continental edge off the eastern United States. Tectonophysics, 59:1-26.

Steiner, M. B., 1975. Mesozoic polar wander and Atlantic plate tectonics. Nature, 245:107-109.

1980. Investigation of the geomagnetic field polarity during the Jurassic. J. Geophys. Res. 85:3572-3586.

Strangway, D. W., 1970. History of the Earth's Magnetic Field: New York (McGraw-Hill Book Co.).

Taylor, P. T., Zietz, I., and Dennis, L. S., 1968. Geologic implications of aeromagnetic data for the eastern continental margin of the United States. Geophysics, 33:755-780.

Umbgrove, J. H. F., 1947. The Pulse of the Earth: The Hague (Nijhoff).

Vail, P. R, Mitchum, R. M., Jr., and Thompson, S., III., 1977. Global cycles of relative changes in sea level. Am. Assoc. Pet. Geol. Mem., 26:83-97.

van Hinte, J. E., 1976. A Jurassic time scale. Am. Assoc. Pet. Geol. Bull., 60:489-497.

Vogt, P. R., 1973. Early events in the opening of the North Atlantic. In Tarling, D. H., and Runcorn, S. K. (Eds.), Implications of Continental Drift to the Earth Sciences (Vol. 2): New York (Academic Press), 693-712.

1975. Changes in geomagnetic reversal frequency at times of tectonic change: evidence for coupling between core and upper mantle processes. Earth Planet. Sci. Lett., 25:313-321.

Vogt, P. R., and Einwich, A. M., 1979. Magnetic anomalies and sea floor spreading in the western North Atlantic, and a revised calibration of the Keathley (M) geomagnetic reversal chronology. In Tucholke, B. E., Vogt, P. R., et al., Init. Repts. DSDP, 43: Washington (U.S. Govt. Printing Office), 971-974.

Watts, A. B., and Steckler, M. S., 1979. Subsidence and eustasy at the continental margin of eastern North America. In Talwani, M., Hay, W., and Ryan, W. B. F. (Eds.), Deep Drilling Results in the Atlantic Ocean: Continental Margins and Paleoenvironment. Am. Geophys. Union, Maurice Ewing Series, 3:218-234.

Yuen, D. A., and Peltier, W. R., 1980. Mantle plumes and the thermal stability of the D" layer. EOS Trans., Am. Geophys. Union, 61: 637.

Yuen, D. A., and Schubert, G., 1976. Mantle plumes: a boundary layer approach for Newtonian and non-Newtonian temperature dependent rheologies. J. Geophys. Res., 81:2499-2510.

Initial Date of Receipt: December 7, 1981 